\title{
Technique for Determining the Potential Use of Disturbed Lands for Agriculture in Mining Region
}

\author{
Kirill Tomilin' ${ }^{1}$, Aleksey Kharitonov ${ }^{2}$, and Nikolay Bondarev ${ }^{3}$ \\ ${ }^{1}$ T. F. Gorbachev Kuzbass State Technical University, 650000, 28 Vesennyaya st., Kemerovo, \\ Russian Federation \\ ${ }^{2}$ Siberian research institute of rural economics SFNZA RAN, Novosibirsk, Russian Federation \\ ${ }^{3}$ Kuzbass State Agricultural Academy, 5 Markovtseva str., Kemerovo, Russian Federation
}

\begin{abstract}
The retrospective dynamics of land use in the Kemerovo region since the Soviet period is presented in the study. The survey of views of the scientific community regarding the development of reclamation of lands allocated to industry was conducted. The statistics are reflected: areas of lands disturbed by the activities of open pits and mines in the mining region; the number of land law violations; land retirement. A technique is presented for determining the potential use of disturbed lands for agriculture in order to identify their suitability or unsuitability for reclamation; its algorithm including seven consecutive stages is presented. Indicators that contribute to maximizing income from each plot suitable for long-term agricultural reclamation were selected.
\end{abstract}

\section{Introduction}

Agriculture of the Kemerovo region is a sector of the economy subject to serious negative influences due to the region's coal mining orientation.

Mining and processing of minerals is a historically established economic dominant. Kuzbass agricultural enterprises are distributed across the territory taking into account the industrial orientation of the region and the recreational opportunities of natural and economic zones. The most suitable lands for agricultural production - the benign soils of the Kuznetsk Basin - hold the main coal reserves of the mining region. Therefore, the development and plowing of the Kuznetsk Basin exceeds the regional average by 2-3 times. Being the most involved in agriculture, the areas of Leninsk-Kuznetsky, Promyshlennovsky, Belovsky, Yaysky and other districts at the same time are the main "owners" of land allocated for industry.

The production of every million tons of coal is accompanied by the loss of an average of 15 hectares of the best arable land. 1 million tons of coal mining growth cause retirement 26-36 hectares of land. A more destructive impact on the environment is exerted only by gold mining.

Val.V. Sencus, V.G. Klimov and V.V. Sencus noted that in 2006-2010 on average in Russia, 6.6 ha of land was annually disturbed per every million tons of coal mined, and half as much was reclaimed. The land disturbance rate has been outstripping the reclamation 
rate for many years; however, the situation seems to remain unchanged in the future. Considering the indicator of the area of lands disturbed by coal production per one resident of the region, the authors came to a figure of more than $200 \mathrm{~m}^{2}$. The cause of this problem, in our opinion, is institutional factors [1]. So, there were seven state offices for reclamation in Kuzbass in the 1970-1980s. There are currently no such offices.

Each ton of coal mined is associated with the production of about 8-10 tons of overburden. Despite the fact that coal mining waste is $99 \%$, of which $97 \%$ is overburden, an increase in coal production in Kuzbass led to the generation of 2.6 billion tons of this kind of waste.

Head of the Department of Natural Resources and Environment of the Kemerovo Region S.V. Vysotsky notes: "Coal-mining enterprises partially use overburden to fill abandoned places, damp truck roads and dams. Unfortunately, taking into account the physical and mechanical properties of overburden, modern technologies simply do not allow re-using it in significant volumes".

During the Soviet Union period, the Kuzbass coal industry was built by the state very clearly and in an orderly manner: economic and environmental standards for land reclamation existed and were strictly observed in accordance with applicable law. In the region on average in 1994-1998 1490 hectares of land were disturbed over a year, 1249 hectares were reclaimed; in 2006-2010 2072 hectares of land were disturbed over a year, 1023 hectares were reclaimed. We also note that the ratio of the total area of disturbed land to the total area of mined land every year over the past $10-15$ years is approximately $85 \%$ and $15 \%$, respectively.

In 2017, official statistics appeared indicating that the rate of 100 thousand hectares of land disturbed in Kuzbass was exceeded. At the same time, the indicator of the area of land disturbed in the Kuzbass during mining amounted to almost 96 thousand ha. At the beginning of 2018, Kuzbass ranked third in the country in terms of the amount of disturbed lands. The results of planned field inspections of the Prosecutor's Office of the Kemerovo Region during state control (supervision) and municipal control in relation to the activities of coal mining enterprises revealed an increase in the amount of disturbed land every year with the reclamation of only $13-18 \%$ of mined land.

The area of lands annually disturbed by mining in 2014-2017 amounted to 3.04 thousand hectares. The average annual indicators of the area of reclaimed lands and the area of mined lands for the same period amounted to 0.989 thousand ha and 1.322 thousand ha, respectively. Over the entire period of mining operations in the Kemerovo region, about 100 thousand hectares of benign land were disturbed and retired and about 300 small rivers were destroyed. Coal mining also led to a change in relief structure, surface displacement, a decrease in soil stability and its infection (high levels of fluorine, lead and zinc). On the other hand, land retirement is understandable - land management measures are consistent with the prospects for economic and social development of the Kemerovo region - Kuzbass. Given that the region is $90 \%$ politically and economically based on coal mining, agricultural lands are rezoned to be industrial.

As noted by E. Pivovarov, in the course of stripping operations in the Kemerovo region, the large mined surface areas were formed. So, the area of land disturbed by open pits and mines is about 92-105 thousand ha (more than $4 \%$ of the Kemerovo region territory).

Annually, 2.0-2.5 thousand hectares are allocated for mining. Reclamation of disturbed lands is mainly of the sanitary-hygienic and recreational purposes. The existing land reclamation technology in practical application is more traditional, based on the use of manual labor, including planting pines and sea buckthorns on disturbed lands. With this approach to reclamation, land does not recover its ecological, economic and social potential. But even with this approach in Kuzbass, for a long time the percentage of 
reclaimed land was one of the lowest in Russia. Reclamation is mainly concentrated in the least costly areas - forestry and water.

Owners of coal mining enterprises often restrict the arable land reclamation by planting trees on the slopes of rock dumps, paying fines for land law violations, which are many times less than capital investments for carrying out appropriate reclamation work.

K.N. Kuropyatnik compares the area of land disturbed in Kuzbass with the area of Singapore and Malta in total, noting that only one fifth of it was reclaimed. The land disturbance "have long exceeded the ability of nature to self-repair" and states that the state authorities in the region should have a more advanced mechanism for state land regulation in order to double the reclamation rate and improve its quality.

Taking into account all the above arguments, we note that the requirement for reclamation of land disturbed during mining can be successfully met with such results of its potential use assessment, which signal the socio-economic justification of reclamation. The difference in the location of plots, the types and quality of soils, topography, forestry area, and other factors affect such indicators as productivity, cost and profit [2]. Assessment of the potential for disturbed land use is an essential element of the system of rational land use of and consists of an assessment of natural fertility, supplemented by an assessment of factors affecting the efficiency of agricultural production.

So, the purpose of the work is to develop a technique for determining the potential use of disturbed lands for agriculture in order to identify their suitability or unsuitability for reclamation.

Achieving the purpose of work predetermines the solution of the following tasks:

1) Collection of information about a plot, taking into account disturbed lands.

2) Consideration of factors (including soil fertility) affecting the potential use of disturbed land for agricultural purposes;

3) Determination of the possible land uses for agricultural purposes.

4) Simulating options for the potential use of disturbed lands and determining the economic effect.

\section{Material and method}

The described technique for determining the potential use of disturbed lands for agriculture in order to identify their suitability or unsuitability for reclamation involves the following principles as its basis:

- regulatory, accounting and evidence data unity;

- completeness and adequacy of the source data;

- reliability and scientific nature of the results obtained;

- validity and appropriateness of scientific approaches.

The described technique is based on system approach, and also uses the following scientific methods:

- Statistical method. It is used to register observations obtained as a result of the survey of land plots and to process the results of simulating the potential use of land plots.

- Analytical method. It is used to study the potential land use structure of and identify properties that affect it.

- Forecast method. Used to generate scenarios for land use and determine the efficiency of each of them.

- Simulation method. It is used to build graphical and mathematical copies of land plots as original objects.

The described method requires the following materials:

- Complete and reliable information about land. 
- Tools and equipment for determining the physical properties and geofixation of land.

- A computer program for visualizing the plot space use.

\section{Results and Discussion}

The need for a technique for determining the potential use of disturbed lands for agriculture in order to identify their suitability or unsuitability for reclamation arises from the conditions of coal mining in the mining region. The data in Table 1 show the dynamics of agricultural land rezoning of the Kemerovo region.

Table 1. Consider the data on agricultural land rezoning in the Kemerovo region from 2003 to 2017.

\begin{tabular}{|l|l|l|l|}
\hline \multirow{2}{*}{ Year } & \multicolumn{3}{|c|}{ Agricultural land rezoning of the Kemerovo region } \\
\cline { 2 - 4 } & $\begin{array}{c}\text { to industrial } \\
\text { category }\end{array}$ & $\begin{array}{c}\text { to specially } \\
\text { protected } \\
\text { area category }\end{array}$ & $\begin{array}{c}\text { to residential } \\
\text { category }\end{array}$ \\
\hline 2003 & $34 \mathrm{ha}$ & - & - \\
\hline 2006 & $199 \mathrm{ha}$ & $4.5 \mathrm{ha}$ & - \\
\hline 2007 & $410 \mathrm{ha}$ & - & $110 \mathrm{ha}$ \\
\hline 2008 & $107 \mathrm{ha}$ & - & $614 \mathrm{ha}$ \\
\hline 2009 & $1123 \mathrm{ha}$ & $23 \mathrm{ha}$ & $1182 \mathrm{ha}$ \\
\hline 2010 & $2301 \mathrm{ha}$ & - & $116 \mathrm{ha}$ \\
\hline 2011 & $4126 \mathrm{ha}$ & - & $7 \mathrm{ha}$ \\
\hline 2012 & $1040 \mathrm{ha}$ & - & - \\
\hline 2015 & $424 \mathrm{ha}$ & - & - \\
\hline 2016 & $4382 \mathrm{ha}$ & - & - \\
\hline 2017 & $5857 \mathrm{ha}$ & - & - \\
\hline Total & $\approx 20000 \mathrm{ha}$ & $27,5 \mathrm{ha}$ & $2028 \mathrm{ha}$ \\
\hline
\end{tabular}

Consider the agricultural land rezoning data by territory, which for a more visual display are graphically represented in the diagram in the Figure.

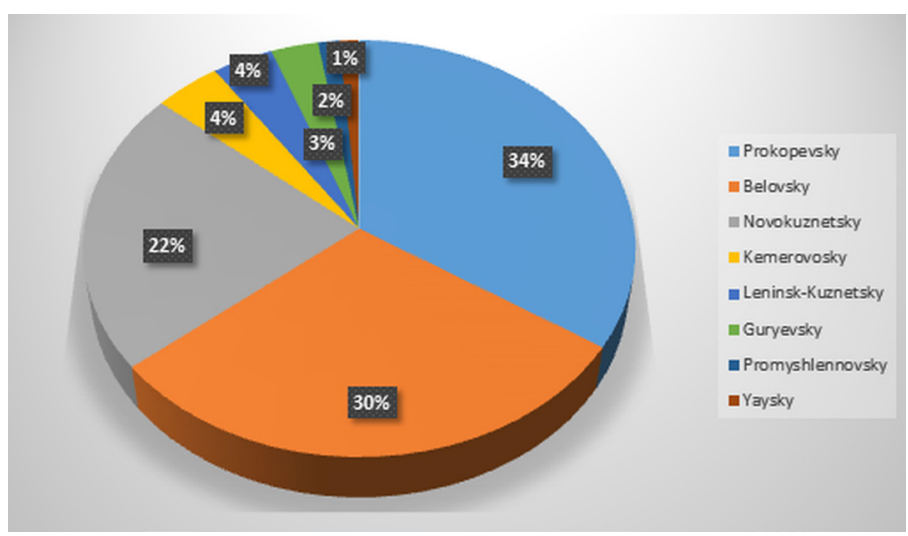

Fig. 1. Structural comparison of agricultural land rezoning in the municipal areas of the Kemerovo region.

Analyzing the data presented, it is determined that during 2003-2017, in Kuzbass, more than 20 thousand hectares of agricultural land were retired, while the average annual rate of their rezoning to industrial land category was more than 1,400 hectares. Analyzing the 
Figure, we can conclude that $86 \%$ of all agricultural land is rezoned in three areas of the region with developed coal industry: Prokopyevsky, Belovsky and Novokuznetsk. The proposed technique acquires greatest significance precisely for these areas, but is relevant for all others [6].

Taking into account the limited land use prevailing in the Kemerovo region, characterized by the disturbance of about 200 thousand hectares of land, with the degradation of about $70 \%$ of soil of the flat territories of the region, a significant increase in public and government interest in greening production, the application of this technique becomes a tool, contributing to the development of agricultural production through land reclamation.

The technique for determining the potential use of disturbed lands for agriculture in order to identify their suitability or unsuitability for reclamation is presented in the following steps.

1. Analytical. The stage provides for familiarization with a land plot: collection, processing and analysis of documentation. The legal registration of a plot, data on its area, the possibilities of doing business, and its transfer to human activity are identified; hypotheses are developed about possible business models.

2. Field research. At the second stage, on-site familiarization with a land plot and its characteristics (at the physical location) is carried out. The purpose is to determine physical condition of land of a plot by examination; topography features, presence of vegetation and its combinations, soil quality are recorded. To increase the accuracy of measurements, the stage can be supplemented by analysis of soil samples.

3. Spatial visualization. The potential use of land in terms of agricultural purposes is determined. Land is investigated in parts - sub-plots. The latter are recorded and grouped according to the possibility of their use on the basis of data obtained at the previous stage. Each sub-plot is thus prepared to the evaluation of its potential for the use for agricultural purposes and the need for reclamation, as well as its feasibility.

4. Land mapping. This stage involves simulating the economic use of a plot with a sequential display of the possibilities of the potential use of every sub-plot.

5. Land use simulation. The stage involves the construction of models for the economic use of land and the evaluation of the effectiveness of each of the hypothetical scenarios of its use for every sub-plot.

6. Testing the model. Testing takes place first in one plot - the observation plot. Then, there is a step-by-step transfer of results to other similar plots.

7. Checking the results of testing and making adjustments. The final stage of the technique involves reflection and the search for ways to improve methods to use land and its subplots. If such methods are discovered, "the issue of creating new infrastructure facilities roads, forest plantations, etc., is being worked out" [5].

The practical significance of the proposed technique for determining the potential use of disturbed lands for agriculture in order to identify their suitability or unsuitability for reclamation is to detect the potential use of a land plot not as a unit of the cadastral plan, but as a combination of different-quality sub-plots with different uses, needs and the justification of reclamation. Each sub-plot has a number of characteristics that determine the most optimal ways of using "in terms of economic efficiency, which leads to the social significance of the process" [4].

Forecast and generation of scenarios for the possible use of sub-plots involves their commercialization (use for sowing crops, livestock grazing, artificial recreational landscaping, etc.). When forecasting the possible use of sub-plots, the indicators of the output of marketable products and their production costs are calculated by the main sectors - crop production, livestock production and the production of all products based on an analysis of information on the agricultural production and marketing [3].

For example, when forecasting land use for hayfields, annual average reproduction rates and the corresponding cost levels will be considered, taking into account the calculation of 
the average yield for the future. The next step is the calculation of the forecast income from land use. The maximum income from each plot will be calculated as the area of land suitable for land reclamation for agricultural needs, multiplied by the projected yield and the projected market value. To do this, it is necessary to determine the following indicators:

- Area of possible land use, hectares;

- Forecast productivity, hundred kilograms per hectare;

- Forecast gross production of hay, hundred kilograms;

- Forecast price, rubles per kilogram.

The projected income obtained according to different scenarios for the use of a land plot and its sub-plots will make it possible to choose the most optimal one in order to determine the potential use of disturbed land for agriculture in order to identify their suitability or unsuitability for reclamation.

This technique is currently undergoing practical testing on the lands of the Belovsky municipal district.

\section{Conclusion}

Thus, the presented technique for determining the potential use of disturbed lands for agriculture in order to identify their suitability or unsuitability for reclamation in the mining region allows identifying land plots and determining the justification and best way of their agricultural use, increasing the reclamation efficiency.

\section{References}

1. N. Bondarev, G. Bondareva, N. Ravochkin, V. Windemut, E3S Web Conf., 105, 04002 (2019)

2. N. Bondarev, P. Kosinskiy, G. Bondareva, European proceedings of social and behavioural sciences, 59, 161-166 (2019)

3. P. D. Kosinsky, N. S. Bondarev, Resources-saving technologies as a factor of stable development in agriculture of Russia Economy of agricultural and processing enterprise (Russia, Moscow, 2014)

4. E. Piskun, V. Khokhlov, Economy of region, 15:2, 363-376 (2019)

5. V. Stukach, G. Saparova, G. Sultanova, S. Saginova, Economy of region, 15:2, 561575 (2019)

6. I. Khorechko, Y. Rogatnev, M. Veselova, T. Filippova, E. Kotsur, International journal of geomate, 17:61 248-256 (2019) 